\title{
Radio Opacity of Honey: A Unique Physical Property with The Potential of A Radio Contrast Media
}

Mohammad Omar Faruq ${ }^{1 *}$, Abul Mokarim², Rafael Mursalin ${ }^{3}$, Md Abu Bin Hasan Susan ${ }^{4}$, Saika Ahmed ${ }^{5}$, Ashiq Haider Choudhury ${ }^{6}$, Gulshan Ara ${ }^{7}$, Ridwan Naim Faruq ${ }^{8}$, Samira Humaira Habib ${ }^{9}$, Md Rezaul Karim ${ }^{10}$, Momana Afrose ${ }^{11}$

\begin{abstract}
Background: Honey is known for its various physical properties, chemical contents and as a topical therapeutic agent. However its potential use in diagnostic radiology has not been reported.

Aims: To establish radio opacity of honey as its unique physical property, to establish its relationship with other physical properties, chemical contents and to determine if honey has any potential as diagnostic contrast media.

Material and Methods: CT scanner was used to calculate radio density in Hounsfield Unit (HU) on six honey samples, honey samples of different dilutions, Iopamidol, 25\% glucose and agents containing Calcium, Iron, Magnesium and Potassium. Plain X-ray was obtained on honey samples, honey filled plastic tubes, and honey impregnated cotton gauze. Radio density of honey samples was compared with four selected physical properties of honey.

Results: Radio density of six honey samples ranged between $287 \pm 3.4 \mathrm{HU}$ and $329 \pm 5.3 \mathrm{HU}$. Radio density of $2 \%$ Iopamidol, a commonly used radio contrast agent was $341 \pm 8.2 \mathrm{HU}$. Compared to honey, 25\% glucose had low radio density and 15\% Potassium chloride had high radio density. Radio density of six honey samples were compared with corresponding density $(p=0.0003)$, specific gravity $(p=0.0002)$, refractive index $(p=0.0001)$ and dynamic viscosity $(p=0.10)$. Plain $X$-ray images of honey samples showed marked radio opacity.

Conclusion: Radio opacity of honey is probably related to its high carbohydrate and potassium content. Honey's anti-bacterial \& healing benefit will offer dual therapeutic and diagnostic advantage with concomitant use as a topical radio contrast agent.
\end{abstract}

Key Words: Honey, Physical property, Radio density.

\section{Introduction}

Honey is produced by bees for nectar collection and long term food storage as honey. ${ }^{1}$ Honey is used in cooking, baking, desserts, and as addition to various beverages such as tea ${ }^{2}$.

In USA honey is graded on its color and optical density by USDA standards and on the Pfund scale which ranges from zero for water white honey to more than 114 for dark amber honey ${ }^{3}$.

Most commercially available honey is a mixture of two or more honeys differing in floral source, color, flavor, density or geographic origin 4 .

Physical and chemical properties of honey vary depending on water content, the type of flora used to produce it, temperatures, and proportion of specific sugars it contains ${ }^{5}$. Honey contains varieties of organic and inorganic substances. Carbohydrates comprise about $82 \%$ of honey. They are monosaccharide like fructose $(38.2 \%)$, glucose $(31 \%)$ and rest are disaccharides and oligosaccharides.

Each 100 Gram of honey contains approximately $20.3 \mathrm{mg}$ of Calcium, $1.4 \mathrm{mg}$ of Iron, $6.8 \mathrm{mg}$ of Magnesium, $13.6 \mathrm{mg}$ of Phosphorous, $176 \mathrm{mg}$ of Potassium, $13.6 \mathrm{mg}$ of Sodium and negligible amount of Zinc, Copper, Manganese, Selenium and Fluoride etc ${ }^{6}$.
One study observed quantities of minerals in different honeys (in ppm) as follows: Potassium (298.60 - 491.40), Magnesium (80.70), Calcium (60.75 - 99.95), Phosphorous (21.10 - 33.29) and Sodium (15.69 - 26.93), Iron (67.18 98.13), Iodine (12.61), Manganese (4.15 - 6.04), Zinc (3.44 5.72) and small amount of Cobalt, Nickel, Lead and Cadmium? ${ }^{7}$.

Honey has a density of around $1.36 \mathrm{Kg} / \mathrm{L}$ and it is $36 \%$ denser than water ${ }^{3}$. Specific gravity of honey is dependent on water content $^{8}$. The melting point of crystallized honey is between $40^{\circ} \mathrm{C}$ and $50^{\circ} \mathrm{C}$ depending on its components ${ }^{9}$.

Viscosity (dynamic) of honey expressed as $\mathrm{mPa} . \mathrm{S}$ (millipascal seconds) is affected by both temperature and water content ${ }^{10}$.

Refractive index of honey is altered by variations in water content. Water content can be measured by the combined formula developed by Wedmore using refractive index and tables developed by Chataway ${ }^{11,12}$. Typically the refractive index for honey ranges from 1.504 at $13 \%$ water content to 1.474 at $25 \%$ water content.

Because honey contains electrolytes in the form of acids and minerals, it exhibits various degrees of electrical conductivity indicating quality of honey in terms of its ash content $t^{12}$. 
Radio opacity (or radio density) refers to relative inability of electromagnetic radiation particularly X-rays to pass through a particular material and it can be quantified according to Hounsfield scale $^{13}$. This principle is central to X-ray Computerized Tomography (CT) scan applications where radio density is expressed as Hounsfield Unit $(\mathrm{HU})^{14}$.

Literatures on physical properties of honey have described specific gravity, density, viscosity, refractive index, electrical conductivity, thermal and optical properties of honey ${ }^{12}$. However there is no report on radio density of honey on current literature search. In our study honey has been observed to have significantly high radio density worthy of further investigation.

\section{Objective}

Objectives of our study was: (1) to establish high radio density of honey as a newly reported physical property, (2) to determine if this characteristics is attributed to any chemical content of honey, (3) to determine if this property is related to other physical properties of honey; and (4) to determine if this unique property has any potential for diagnostic use.

1. Mohammad Omar Faruq, MD, FCCM, FACP, FACEP, FCPS, Professor of Critical care Medicine, United Hospital Limited, Dhaka 1212, Bangladesh.

2. Abul Mokarim, MBBS, DTM, PhD, Chief Consultant Radiologist, IbnSina Diagnostic and Imaging Center, Dhaka 1209, Bangladesh.

3. Rafael Mursalin, MBBS, PhD, Consultant Radiologist, IbnSina Diagnostic and Imaging Center, Dhaka 1209, Bangladesh.

4. Md Abu Bin Hasan Susan, MSc, PhD, Professor, Dept. of Chemistry, Dhaka University, Dhaka 1000, Bangladesh.

5. Saika Ahmed, MS, PhD, Assistant Professor, Dept. of Chemistry, Dhaka University, Dhaka 1000, Bangladesh.

6. Ashiq Haider Choudhury, MBBS, Research Assistant, IbnSina Hospital, Dhaka 1209, Bangladesh.

7. Gulshan Ara, PhD student, Dept. of Chemistry, Dhaka University, Dhaka 1000, Bangladesh.

8. Ridwan Naim Faruq, MBBS, Lecturer, Ibrahim Medical College, Dhaka 1000, Bangladesh.

9. Samira Humaira Habib,MSc, MPhil, Principal Research Officer, Health economics unit, Diabetic Association of Bangladesh, Dhaka 1000, Bangladesh.

10. Md Rezaul Karim, MBBS, Resident Medical officer ICU, IbnSina Hospital, Dhaka 1209 , Bangladesh.

11. Momana Afrose, M Phil student. Dept. of Chemistry, Dhaka University, Dhaka 1000, Bangladesh.

\section{*Corresponding Author:}

Dr. Mohammad Omar Faruq

MD, FACP, FACEP, FCCM, FCPS

Professor of Critical care Medicine and Consultant ICU,

United Hospital Limited, Plot 15, Road 71, Gulshan

Dhaka 1212, Bangladesh.

Cell: +8801674999897

E mail: faruqmo@yahoo.com

\section{Materials and Methods}

This was a prospective observational study carried out between Aug 2016 and April 2017 at a local hospital and at a local university.

Each study sample of honey and other study liquids were kept in $10 \mathrm{cc}$ plastic syringes at room temperature and appropriately labeled before use. We obtained radio density of the study samples (Fig 1, 2 \& 3; Table 1, 2 \& 3) calculated in HU by using a CT scanner (SIEMENS Model - SOMATOM Definition AS + slice 128).

We used SIEMENS 1000 MA digital X-ray machine to obtain $\mathrm{X}$-ray images of designated study samples.

We randomly chose six different samples of honey obtained from a local supermarket (Table 1 A-F). Samples A \& E, samples B, C \& D and sample F were from Australia, Bangladesh and Saudi Arabia respectively.

We estimated radio density of six honey samples (Table 1 A-F). We estimated radio density of Iopamidol 370 (undiluted and $02.0 \%$ soln.) which is an intravenous radio contrast agent used by radiologists at our imaging center, sample B honey of four different strengths $(100 \%, 75 \%, 50 \%, 25 \%$ in water $)$, $25 \%$ Glucose (Table $2 \mathrm{a}-\mathrm{g}$,). Then we estimated radio density of 10\% Calcium gluconate solution, 4\% Magnesium Sulphate solution, 2\% Iron Sucrose solution and 15\% Potassium Chloride solution (Table 3 I- IV).

We obtained X-ray images of study samples in $10 \mathrm{CC}$ plastic syringes mentioned in Table $2 \mathrm{a}-\mathrm{g}$.

We obtained X-ray images of a sample of honey contained in a plastic syringe, a honey filled plastic tube, a plastic tube filled with honey and air bubbles, and a piece of cotton gauze impregnated with honey.

Density and specific gravity of study samples (A - F) of honey were measured simultaneously with an Anton Paar (Model DMA 5000) vibrating-tube density meter at $25^{\circ} \mathrm{C}^{15}$. Refractive indices of study samples (A - F) were measured at $25^{\circ} \mathrm{C}$ using Anton Paar Abbemat-350 automated refractometer ${ }^{16}$.

We used Ostwald viscometer ${ }^{17}$ to measure dynamic viscosity of study samples $(\mathrm{A}-\mathrm{F})$ at $22.0^{\circ} \mathrm{C}$.

Results of radio density of study samples (A - F) were compared with density, specific gravity, refractive index and viscosity of corresponding samples. The data were analyzed by using SPSS version-20. Radio density of honey expressed in $\mathrm{HU}$ was considered as dependent variable and density (expressed in gm/cubic cm), specific gravity, refractive index and viscosity (expressed in mpa.s) were considered as independent variables. One sample T test was used to observe the level of significance. $P$-value $<0.05$ was considered as statistically significant.

\section{Results}

Radio density of study samples A - F calculated by plain CT scanner in HU (Mean \pm SD) are shown at Table $1 \mathrm{~A}-\mathrm{F}$ and with corresponding CT axial image at Fig $1 \mathrm{~A}-\mathrm{F}$.

Table $2 \mathrm{a}-\mathrm{g}$ and Fig $2 \mathrm{a}-\mathrm{g}$ show radio density of designated study samples described in materials and methods with corresponding CT axial image. 
Table 3 I - IV and Fig 3 I - IV and show radio density of four different intra venous therapeutic agents containing Calcium, Magnesium, Iron and Potassium respectively with corresponding CT axial image as described in materials and methods.

Table 4 shows radio density of sample A to F compared with density, specific gravity, refractive index and dynamic viscosity with mean $\pm \mathrm{SD}$ and calculated $p$ value for each set of physical properties.

Fig 4 shows X-ray images of 100\% Iopamidol 370, 2\% Iopamidol 370 , four concentrations of sample B honey and $25 \%$ glucose ( see Table $2 \mathrm{a}-\mathrm{g}$ ) arranged from above down.

Fig 5 shows X-ray image of a sample of honey filled plastic syringe (a), honey filled plastic tube (b), plastic tube filled with honey and air bubbles (c), and a piece of cotton gauze impregnated with honey (d).

\section{Discussion}

We have studied six honey samples (A - F) all locally procured (both native and foreign origin). All these samples showed radio density ranging from $287 \pm 3.4 \mathrm{HU}$ to $329 \pm 5.3$ HU (Table $1 \mathrm{~A}$ - F). We also observed that 2\% Iopamidol 370 which is a intravenous contrast media used in our study hospital with a radio density of $341 \pm 8.2 \mathrm{HU}$ (Table $2 \mathrm{~b}$ ). So radio density of $2 \%$ Iopamidol is comparable to radio density of honey samples used in our study.

Carbohydrates comprise about $82 \%$ of honey according to different literature ${ }^{5}$. Out of them Fructose (38.2\%) and glucose (31\%) are the most abundant.

$25 \%$ Glucose has a radio density of $52.3 \pm 10.3 \mathrm{HU}$ (Table 2 g) and $25 \%$ honey has radio density of $63.1 \pm 4.7 \mathrm{HU}$ (Table $2 \mathrm{f}$ ). So it can be hypothesized that fructose (radio density not measured) and glucose together may contribute to overall radio density of honey.

As honey contains significant amount of Potassium, Calcium, Iron and Magnesium, we examined four different therapeutic intravenous agents mentioned in Table 3 I - IV. 15\% Potassium chloride soln. was found to have significantly high radio density of $372.9 \pm 9.6 \mathrm{HU}$ and it is comparable to that of honey. According to literature, Potassium is the most abundant mineral (one third of mineral content of honey) observed in honey ${ }^{18,19}$. So it can be hypothesized that significant Potassium content could also be responsible for the radio opacity of honey.

We chose density, specific gravity, refractive index and dynamic viscosity and we compared the results of these four physical properties of all six honey samples (A - F) with respective radio density. We observed that radio density of all the study samples were positively correlated with density, specific gravity, refractive index with significantly low $p$ value $(.0003, .0002, .0001$ respectively) with the exception of dynamic viscosity $(p=0.10)$. (Table 4 )

Lastly we examined X-ray images of honey filled plastic syringes (Fig 4; also note Fig 2 \& Table 2), honey filled plastic tube, plastic tube containing honey with air bubbles, honey impregnated cotton gauze (Fig $5 \mathrm{a} b \mathrm{~cd}$ ). These images indicate that honey has significant radio density on plain $\mathrm{X}$-ray.

We believe that honey has the potential to be used by radiologists for imaging sinus, fistula, outlining salivary duct, and urethra etc. Honey impregnated cotton gauze can also be used by surgeons to pack external wounds and internal cavities (like peritoneal cavity) during operative procedures. The location of the packing is expected to be visualized and confirmed by plain X-ray. Similarly if honey is injected into bursa, cysts, etc. dimensions of cavities is expected to be outlined by plain X-ray.

Various literatures describe abundant therapeutic benefits of honey. Honey promotes healing of wound dehiscence ${ }^{20}$. It prevents formation of biofilm and is superior to antimicrobial dressing $^{21}$. It promotes debridement of wounds and accelerates wound closure $^{22}$. It has broad spectrum antimicrobial activities and clears severely infected skin wounds ${ }^{23}$. Honey enhances healing in burn wounds ${ }^{24}$.

\section{Conclusion}

It can be concluded that honey as a topical radio contrast agent, has dual application potential both therapeutic and diagnostic. Our study is a preliminary study. So combination of therapeutic application of honey in healing of lesions as out lined in the previous paragraph together with the diagnostic potential of X-ray and CT imaging of the some lesions will open up potentially vast areas of research. We also conclude that radio opacity of honey is a newly identified physical property which needs further study to determine more accurately its relationship with its various physical properties and chemical contents.

\section{Acknowledgement}

We are grateful to Ibn Sina Diagnostic and Imaging center, Dhaka and chemistry lab of University of Dhaka for their technical support in conducting our studies. This study was self- funded. There is no conflict of interest. 
Table-I

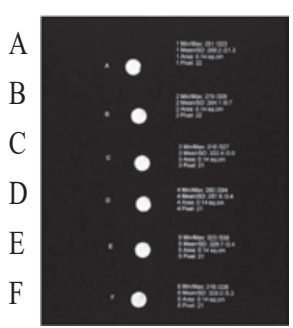

Fig 1

\begin{tabular}{llc}
\hline & \multicolumn{1}{c}{ Mean $\mathrm{HU} \pm \mathrm{SD}$} \\
\hline A & Ausie bee & $288.2 \pm 21.3$ \\
B & Dabur honey & $294.1 \pm 9.7$ \\
C & AP honey Sundar ban & $322.4 \pm 3.0$ \\
D & Haradighi & $287.8 \pm 3.4$ \\
E & Capilano & $328.7 \pm 3.4$ \\
F & AlShifa acacia honey & $329.0 \pm 5.3$ \\
\hline
\end{tabular}

Table-2

\begin{tabular}{|c|c|c|c|c|}
\hline & & \multicolumn{3}{|c|}{ Mean $\mathrm{HU} \pm \mathrm{SD}$} \\
\hline $1=$ & 0 & $\mathrm{a}$ & $100 \%$ Iopamidol 370 & $3071 \pm 0.0$ \\
\hline 1 & 0 n-m & b & 02\% Iopamidol 370 & $341.0 \pm 8.2$ \\
\hline i & $0=$ & $\mathrm{c}$ & $100 \%$ honey & $305.1 \pm 18.3$ \\
\hline : & 0 mm & d & $75 \%$ honey & $243.2 \pm 12.4$ \\
\hline : & 0 & $\mathrm{e}$ & $50 \%$ honey & $152.9 \pm 9.4$ \\
\hline : & $0 \mathrm{~mm}$ & $\mathrm{f}$ & $25 \%$ honey & $63.1 \pm 4.7$ \\
\hline Hex & 0 man & g & $25 \%$ glucose & $52.3 \pm 10.3$ \\
\hline
\end{tabular}

Fig 1

Table-3

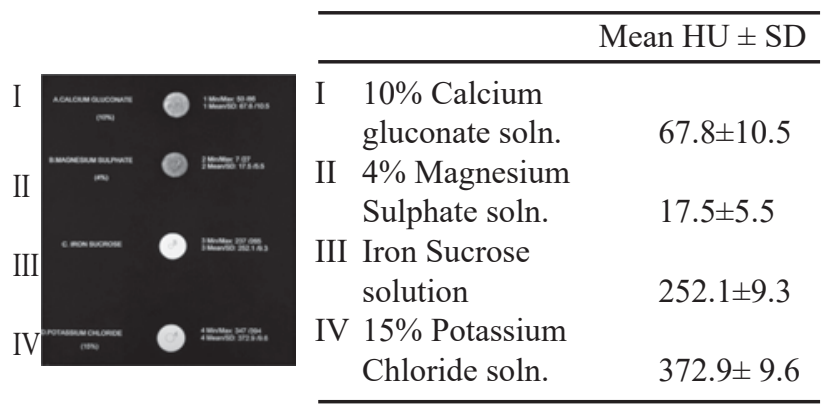

Bangladesh Crit Care J September 2018; 6 (2): 95-99

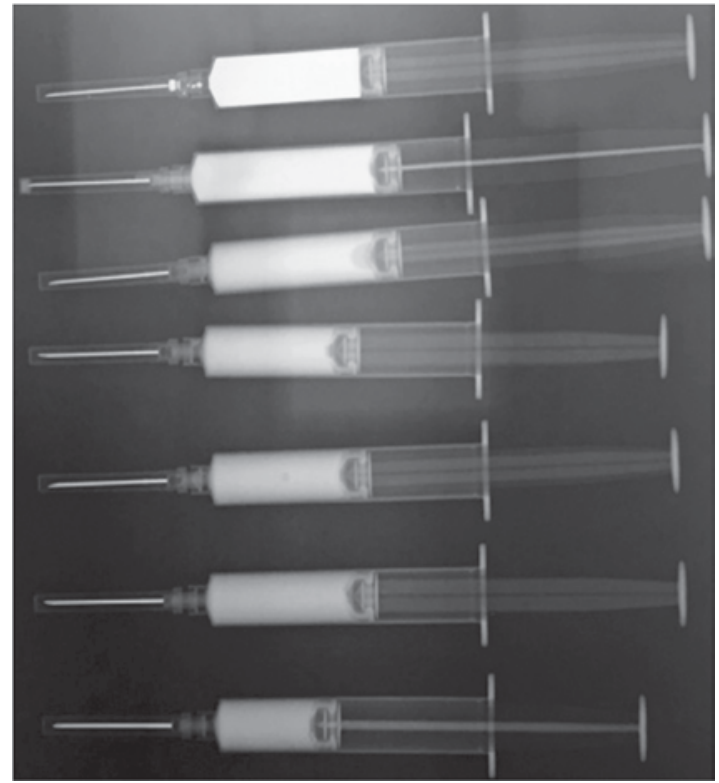

Fig 4

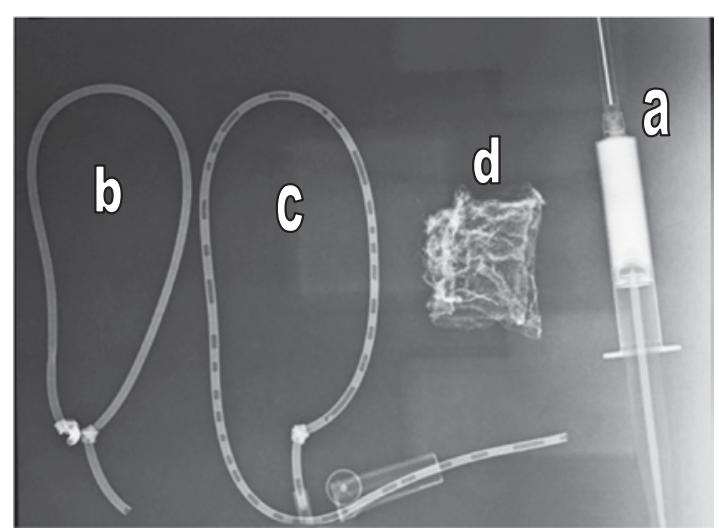

Fig 5

Fig 3

Table-4

\begin{tabular}{|c|c|c|c|c|c|c|c|c|c|}
\hline $\begin{array}{l}\text { Study } \\
\text { samples } \\
\text { of honey }\end{array}$ & $\begin{array}{c}\text { Radio density } \\
\text { HU: Mean } \pm \text { SD }\end{array}$ & $\begin{array}{c}\text { Density } \\
\mathrm{gm} / \mathrm{cm} 3\end{array}$ & P value & $\begin{array}{l}\text { Specific } \\
\text { gravity }\end{array}$ & P value & $\begin{array}{c}\text { Refractive } \\
\text { index }\end{array}$ & P value & $\begin{array}{l}\text { Viscosity } \\
\text { mpa.s }\end{array}$ & P value \\
\hline $\mathbf{A}$ & $288.2 \pm 213$ & 1.41412 & & 1.41053 & & 1.489760 & & 2519.87 & \\
\hline B & $294.1 \pm 9.7$ & 1.40715 & & 1.40715 & & 1.489130 & & 2098.18 & \\
\hline $\mathbf{C}$ & $322.4 \pm 3.0$ & 1.41021 & & 1.411440 & & 1.489260 & & 3409.14 & \\
\hline D & $287.8 \pm 3.4$ & 1.218 & & 1.222 & & 1.474750 & & 355.76 & \\
\hline $\mathbf{E}$ & $328.0 \pm 3.4$ & 1.41907 & & 1.422390 & & 1.493500 & & 5672.30 & \\
\hline \multirow[t]{2}{*}{$\mathbf{F}$} & $329.0 \pm 5.3$ & 1.42159 & & 1.42581 & & 1.492630 & & 4693.04 & \\
\hline & & & .0003 & & .0002 & & .0001 & & .010 \\
\hline
\end{tabular}




\section{References}

1. Suarez R K, Lighton J R, Joos B, Roberts SP, Harison JF . Energy metabolism, enzymatic flux capacities and metabolic flux rates in flying honey bees. Proc Natl Acad Sci USA 1996; 93: 12616-20.

2. Hunt C L, Atwater H W. Honey and its uses in the home. In: Farmer's bulletin no 653, Chapter 2. Washington D. C: U.S. Dept of Agriculture; 1915

3. FAO Corporate Document Repository [Internet]. Krell R: Value added products from bee keeping. Rome: FAO of the UN; c1996 [cited 2016 Jun 5]. Available from: http://www.fao.org/docrep/w0076e/w0076e00.htm.

4. National Honey Board. Definition of honey and honey products. 1996 Jun [updated 2003 Sep 23]

5. White Jr. J W, Doner L W. Honey composition and properties. Bee keeping in United States Agricultural Handbook 1980; 335: 82 - 91.

6. Nutritiondata.self.com [Internet]. Honey Nutrition Facts and Calories. C2014 Jan 2 - [cited 2016 Jan 5]. Available from: http://nutritiondata.self.com/facts/sweets/5568/2.

7. 24. Alqarani A S, Owayss A A, Mahmoud A A, Hannan MA . Mineral content and physical properties of local and imported honeys in Saudi Arabia. J Saudi Chem Soc 2014; 18: 618-25.

8. Honey.com [Internet]. National Honey Board. Honey: A reference guide to nature's sweetener. C2005 Jul 26 - [cited 2016 Jan 5]. Available from: https://honey.com/files/general/refguide.pdf.

9. Root A I, Root E R. The ABC and XYZ of Bee Culture. 2005 ed. Montana: Kessinger Publishing; 2005.

10. 15, 18. Bee-Hexagon.net [Internet] Bogdanov S. (2009). Physical properties of honey. In: Book of honey, Chapter 4. C2009 Aug [updated 2011 May, cited on 2016 Jan 5]. Available from: http://www.bee-hexagon.net/honey/.

11. Wedmore E B. The accurate determination of water content of honeys. The Bees World 1955; 36: 197-206.

12. Chataway H D. Honey tables showing relationship between various hydrometer scales and refractive index to moisture content and weight per gallon. Can J Res 1935; 6: 532-47.

13. Hounsfield GN. Computed medical imaging. Nobel lecture, J Comp Assist Tomogr. 1980; 4: 665-74
14. Schreiber J J, Anderson P A, Rosas H G, Buchholz AL, Au AG. Hounsfield units for assessing bone mineral density and strength: A tool for osteoporosis management. Journal of Bone \& Joint Surgery. American Volume: 1 June 2011; 93: 1057-63.

15. H \& D Fitzgerald [Internet]. Fitzgerald D. Technical assessment of the Anton Paar DMA 5000 density meter. C 2000 Jan 10 - [cited 2016 Jun 5]. Available from: https://density.co.uk/wp-content/uploads/2012/02/review_of_5000. pdf.

16. The buyer's guide for laboratory equipment [Internet]. Abemat300/350 Refractometer from Anton Paar. C 2011 Mar 6 [cited 2016 Jun 5]. Available from: http://www.labcompare.com/402-Automatic-Refractometer/5007Abbemat-300-350-Refractometer/.

17. Alam M, Akhtar M, Asif H. Viscosity. In: Textbook of Practical Analytical Chemistry, Chapter 6.2. El Sevier: 2011.

18. Bogdanov S, Haldmann M, Luginbuhl W, Gallmann P. Minerals in honey: Environmental, geographical and botanical aspects. J Apicult Res 2007; 46: 269-75.

19. Chakir A, Romane A, Barbagianni N, Bartoli D, Ferrazzi P. Major and trace elements in different types of Moroccan honeys. Aust J Basic \& Appl Sci 2011; 5: 223-31.

20. Anyanechi C E, Saheeb B D. Honey and wound dehiscence: A study of surgical wounds in the mandibular bed. Niger J Clinic Pract 2015; 18: 251-55.

21. Halstead F D, Webber M A, Rauf M A, Burt R, Dryden M, Oppenheim BA . In vitro activity of an engineered honey, medical grade honeys, and antimicrobial wound dressing against biofilm producing clinical bacterial isolates. J Wound Care 2016; 25: 93-94.

22. Majtan J. Honey: An immune modulator in wound healing. Wound repair Regen 2014; 22: 187-92.

23. Israili Z H. Antimicrobial properties of honey. Am J Ther 2014; 21: 304-23.

24. Gupta S S, Singh O, Bhagel P S, Moses S, Shukla S, Mathur RK. Honey dressing versus Silver Sulfadiazine dressing for wound healing in burn patients: A retrospective study. J Cutan Anesthet Surg 2011; 4: 183-87. 